Tropical Journal of Pharmaceutical Research April 2015; 14 (4): 591-598

ISSN: $1596-5996$ (print); 1596-9827 (electronic)

(C) Pharmacotherapy Group, Faculty of Pharmacy, University of Benin, Benin City, 300001 Nigeria.

All rights reserved.

Available online at http://www.tjpr.org

Original Research Article

http://dx.doi.org/10.4314/tjpr.v14i4.5

\title{
Purification and Characterization of Thermostable Cellulase from Consortium XM70 in Terrestrial Hot Spring with Sugarcane Bagasse
}

\author{
Chao Zhao ${ }^{1}$, Xiong Lu ${ }^{1}$, Yunjin Deng ${ }^{1}$, Yifan Huang ${ }^{1,2 *}$ and Bin Liu ${ }^{1,2 *}$ \\ ${ }^{1}$ College of Food Science, Fujian Agriculture and Forestry University, ${ }^{2}$ National Engineering Research Center of JUNCAO, \\ Fuzhou 350002, China
}

*For correspondence: Email: zjhyfang@163.com, binliu618@163.com; Tel: 86-591-83530197; Fax: 86-591-83530197

Received: 10 November 2014

Revised accepted: 13 March 2015

\begin{abstract}
Purpose: To better understand the sugarcane bagasse (SCB) degradation process and obtain thermostable cellulase from terrestrial hot spring.

Methods: Molecular community structure of the newly selected thermophilic bacterial consortium XM70 was determined using the method of the full-length 16S rRNA library-based analysis. The thermostable CMCase was purified with ion-exchange and gel filtration chromatography.

Results: Sequence-based identification of species belonging to the genera, Geobacillus, Desulfotomaculum, Bacillus, Exiguobacterium, Paenibacillus and Enterobacter were identified. The maximal activities of carboxymethyl cellulase (CMCase), filter paper cellulase and $\beta$-glucosidase of the consortium XM70 were obtained after incubation at $60^{\circ} \mathrm{C}$ and $\mathrm{pH} 6.0$ (4 days), $80^{\circ} \mathrm{C}$ and $\mathrm{pH} 7.0$ (2 days) and $70{ }^{\circ} \mathrm{C}$ and $\mathrm{pH} 8.0$ (4 days), respectively. The yield of reducing sugars in the culture broth achieved $0.11 \mathrm{~g} . \mathrm{g}^{-1}$ dry SCB. An extracellular CMCase from consortium XM70 (XM70-CMCase) was purified 7.9-fold to apparent homogeneity with a recovery of $65.41 \%$ and its molecular mass was about $31.0 \mathrm{kDa}$. Maximum CMCase activity of the purified XM70-CMCase was $3.77 \mathrm{U} / \mathrm{mg}$ at $70{ }^{\circ} \mathrm{C}$ and $\mathrm{pH}$ 7.0. CMCase activity maintained about its maximal value of $70 \%$ after incubation at $80{ }^{\circ} \mathrm{C}$ for $60 \mathrm{~min}$. Conclusion: Due to its high temperature stability, the purified XM70-CMCase may be useful for industrial application such as biofuel, animal feed industry, paper industry and clarification of fruit juices.
\end{abstract}

Keywords: Thermostable cellulase, Sugarcane bagasse, Purification, Characterization, Hot spring

Tropical Journal of Pharmaceutical Research is indexed by Science Citation Index (SciSearch), Scopus, International Pharmaceutical Abstract, Chemical Abstracts, Embase, Index Copernicus, EBSCO, African Index Medicus, JournalSeek, Journal Citation Reports/Science Edition, Directory of Open Access Journals (DOAJ), African Journal Online, Bioline International, Open-J-Gate and Pharmacy Abstracts

\section{INTRODUCTION}

The unstable and uncertain petroleum sources and the rising cost of fuels have created concern when it comes to burning fossil fuels [1]. These concerns have shifted global efforts to utilize biomass as an alternative resource, which is considered as being a 'greener' energy source and can also meet the high energy demand.
Sugarcane bagasse (SCB) is one of the most abundant byproducts of agro-industry in the world, creating 540 million tons of residues per year $[2,3]$. It is a porous residue of cane stalks left over after the crushing and extraction of the juice from sugarcane, and is composed of 19 $24 \%$ lignin, 27 - $32 \%$ hemicellulose, 32 - $44 \%$ cellulose and $4.5-9 \%$ ashes [4,5]. SCB has been used extensively because of its availability and high volume/low cost production potential. One of the key steps to utilizing SCB is the 
efficient hydrolytic conversion of cellulose into soluble sugar [2]. There has been vast interest in bacterial consortium for converting cellulosic biomass to glucose. Compared to a single bacterium, bacterial consortium can produce more efficient and novel enzymes, which have great potential for bioenergy.

Cellulases are used in the agri-food, brewery wine, animal feed, textile laundry and paper industries [6]. Wide ranges of applications have made cellulase one of the most desirable enzyme systems. However, the mesophilic enzymatic hydrolysis technologies exhibit slow enzymatic hydrolysis rates, generate low yields of sugars, require high dosages of enzymes and are prone to microbial contamination problems [7]. These limitations could be overcome by using thermophilic bacteria and thermostable enzymes [8]. Highly thermostable cellulases are not only accompanied with less viscosity and microbial contamination [9], but also with increased reaction rate and reduced hydrolysis time [10]. Thermophilic cellulose-degrading bacteria have been isolated from various environments [11]. Researches have focused on enhancing thermostable cellulase activity to improve the yield and rate of enzymatic hydrolysis [12-14].

An efficient conversion of the SCB to soluble sugar requires synergistic action of various enzymes. The thermal and $\mathrm{pH}$ stability affect the potential application of the enzymes in largescale cellulose hydrolysis process. Currently, one of the major bottlenecks is that the thermostable cellulase which can work efficiently and inexpensively at high temperature condition is insufficient, although much attention has been paid to the thermophilic bioprocessing of cellulosic biomass to glucose $[15,16]$. In this study, we identified the selected efficient thermophilic SCB-degrading consortium XM70 and described the purification and characterization of the purified thermostable cellulase. Cultural factors affecting cellulase production were also investigated in order to optimize the fermentation conditions for production maximization.

\section{EXPERIMENTAL}

\section{Sample collection and consortium enrichment}

The water column and sediment samples were aseptically obtained from a terrestrial hot spring in Xiamen, China (where the temperature was above $70{ }^{\circ} \mathrm{C}$ ) using sterile equipment. The samples were transported to the laboratory in sterile polypropylene tubes in ice and stored at $20{ }^{\circ} \mathrm{C}$ until analyzed. The medium used for the culture contained (per liter): $10 \mathrm{~g}$ pretreated SCB, $1 \mathrm{~g}$ peptone, $10 \mathrm{~g}$ yeast extract, $2 \mathrm{~g}\left(\mathrm{NH}_{4}\right)_{2} \mathrm{SO}_{4}$, $0.5 \mathrm{~g} \mathrm{MgSO}_{4}, 1 \mathrm{~g} \mathrm{KH}_{2} \mathrm{PO}_{4}, 0.5 \mathrm{~g} \mathrm{NaCl}, 1 \mathrm{~mL}$ $\mathrm{MnSO}_{4} \cdot \mathrm{H}_{2} \mathrm{O}(0.25 \%)$ and $1 \mathrm{~mL} \mathrm{FeSO} \cdot \cdot 7 \mathrm{H}_{2} \mathrm{O}$ $(0.75 \%)$. The SCB was dried and chopped into small pieces by a hammer mill and finally separated by 40 mesh sieve. The pre-treatment of the SCB was carried out with $2 \%(w / v) \mathrm{NaOH}$ at $85{ }^{\circ} \mathrm{C}$ for $75 \mathrm{~min}$. The pre-treated residues were washed extensively to neutral $\mathrm{pH}$ and dried to constant weight at $65{ }^{\circ} \mathrm{C}$ [3]. Two grams of samples were inoculated in $250-\mathrm{mL}$ conical flasks containing $100-\mathrm{mL}$ of sterilized minimal growth medium. The culture was performed by incubating the conical flasks at $70{ }^{\circ} \mathrm{C}$ in an incubator shaker (120 rpm) for 6 days. Cultures showing growth were subcultured ten times into fresh medium to obtain the stable thermophilic bacterial consortium.

\section{Structure dynamics of thermophilic bacterial consortium}

For molecular characterization of the bacterial consortium, 16S rRNA gene cloning and sequencing analyses were performed. The genomic DNA was extracted using the Bacterial DNA Isolation Kit (Sangon Biotech, Shanghai, China) according to the manufacturer's protocol. The 16S rRNA genes of the bacterial consortium were amplified by PCR using primers $27 \mathrm{~F}$ and 1492R [17]. The process of PCR was under the following conditions: $94{ }^{\circ} \mathrm{C}, 5 \mathrm{~min} ; 30$ cycles of $94{ }^{\circ} \mathrm{C}, 45 \mathrm{~s} ; 55^{\circ} \mathrm{C}, 45 \mathrm{~s}$; and $72{ }^{\circ} \mathrm{C}, 90 \mathrm{~s} ; 1$ cycle of $72{ }^{\circ} \mathrm{C}, 10 \mathrm{~min}$; and then $4{ }^{\circ} \mathrm{C}$ continuously. The 16S rRNA genes with the expected size (about $1500 \mathrm{bp}$ ) were purified using a DNA Gel Extraction Kit (Sangon Biotech, Shanghai, China) and cloned into pMD18-T vector (Takara, Kyoto, Japan) followed by sequencing. After that, sequence analysis was performed using the BLAST algorithm. To test the evolutionary relationships, phylogenetic analysis was performed with the program MEGA 4.0 [18]. Multiple alignments of the sequences were performed using CLUSTAL W. Bootstrap values were determined based on 1,000 replications.

\section{Enzyme assays and sugar yield analysis}

The major cellulase component activities were characterized by assays of carboxymethyl cellulase (CMCase), filter paper cellulase (FPase) and $\beta$-glucosidase [19]. The CMCase and FPase activities were determined using the IUPAC standard procedure [20]. The $\beta$ - 
glucosidase activity was assessed using salicin as substrate by Chahal's method [21]. The reducing sugar liberated in the reaction mixture was measured by the dinitrosalicylic acid method [22]. One unit (U) of the activity was defined as the amount of enzyme releasing $1 \mu \mathrm{M}$ reducing sugar per minute under the assay conditions. The specific activity was expressed in $\mu \mathrm{mol} / \mathrm{min} / \mathrm{mg}$ protein. The culture was centrifuged at $7000 \mathrm{rpm}$ in $4{ }^{\circ} \mathrm{C}$ for $20 \mathrm{~min}$ and then the supernatant was used as crude enzyme in the determination of cellulase activities and sugar yield.

\section{Quantification of cellulase activities in different cultural conditions}

In order to examine the effects of temperature and $\mathrm{pH}$ on enzyme activities, the bacterial consortium was grown in a $100-\mathrm{mL}$ of medium containing $1 \mathrm{~g}$ pre-treated SCB. The temperature of the culture varied from $50{ }^{\circ} \mathrm{C}$ to $90{ }^{\circ} \mathrm{C}$ with increments of ten degrees unit and the $\mathrm{pH}$ of the growth medium varied from 5.0 to 9.0 with increments of one $\mathrm{pH}$ unit using sodium citrate buffer (50 mM, pH 5.0-6.0), sodium phosphate buffer (50 mM, pH 7.0 - 8.0) and glycine- $\mathrm{NaOH}$ buffer (50 mM, pH 9.0). The enzyme assay was carried out as described in the preceding section after 2 days of active growth. The enzyme activities obtained at the optimal medium temperature and $\mathrm{pH}$ were used to calculate the relative percentage enzyme activity produced at other temperatures and $\mathrm{pH}$ values. In order to determine the optimal incubation time for cellulase activities and sugar yield, the inoculated flasks were incubated at $70{ }^{\circ} \mathrm{C}$ and $\mathrm{pH} 7.0$ for a period of 8 days. Culture samples were collected on $0,1,2,4,6$ and 8 days during the cultivation period. The supernatants were analyzed for cellulase activities and sugar yield as described previously. The maximum enzyme activities obtained at a particular incubation time were considered as $100 \%$ and used to calculate the relative enzyme activity in presence of other incubation times.

\section{Purification and characterization of XM70- CMCase}

Bacterial cells were removed from culture broth by centrifugation at $7000 \mathrm{rpm}$ for $20 \mathrm{~min}$ at $4{ }^{\circ} \mathrm{C}$. First, the cell free supernatant was overnight precipitated to $80 \%$ saturation with $\left(\mathrm{NH}_{4}\right)_{2} \mathrm{SO}_{4}$ at $4{ }^{\circ} \mathrm{C}$ and then the precipitated proteins were recovered by centrifugation [23]. The precipitate was dissolved in $20 \mathrm{mM}$ sodium phosphate buffer $\mathrm{pH}$ 7.0. Then, for ion exchange chromatography, the sample was applied to DEAE Sephadex A-25 column equilibrated with a linear gradient of $0.1-1.0 \mathrm{M} \mathrm{NaCl}$ in the same buffer. At last, the fraction with the highest CMCase activity was further purified by gel filtration on Sephadex G-75 column with same buffer. The fractions were eluted at a flow rate of $1 \mathrm{~mL} / \mathrm{min}$. A total of 20 fractions were collected and assayed for CMCase activity. Fraction showing the maximum activity was selected for studying the purification and characteristics of the enzyme (XM70-CMCase).

Protein concentration of the XM70-CMCase enzyme was measured by using the Bradford method and the standard curve was prepared by using bovine serum albumin (BSA) as standard [24]. Sodium dodecyl sulfate-polyacrylamide gel electrophoresis (SDS-PAGE) was performed according to the method of Laemmli [25]. After electrophoresis, the gels were stained by a solution of $0.1 \%(\mathrm{w} / \mathrm{v})$ Commassie blue, $30 \%$ $(\mathrm{v} / \mathrm{v})$ methanol and $10 \%(\mathrm{v} / \mathrm{v})$ acetic acid. Enzyme assay for XM70-CMCase were conducted in 3-mL reaction volumes containing 1 $\mathrm{mL}$ of an appropriate dilution of enzyme and 2 $\mathrm{mL}$ of $1 \%$ (w/v) CMC solubilized in $200 \mathrm{mM}$ sodium phosphate buffer $(\mathrm{pH} 7.0)$. The optimal temperature of XM70-CMCase was determined at different temperature ranging from 30 to $90{ }^{\circ} \mathrm{C}$ after incubation for $30 \mathrm{~min}$. The optimum $\mathrm{pH}$ of $\mathrm{XM70}$-CMCase was estimated in the $\mathrm{pH}$ range of 4.0 - 10.0 using different assay buffers at the optimum temperature as described above. The enzyme activities obtained at the optimal temperature and $\mathrm{pH}$ were used to calculate the relative percentage enzyme activity produced at other temperatures and $\mathrm{pH}$ values. The thermal stability of CMCase was tested by determining the enzyme activity remaining after incubation of the enzyme at different temperatures (70 - 100 ${ }^{\circ} \mathrm{C}$ with increments of $10{ }^{\circ} \mathrm{C}$ ) for a period of 60 min. The residual activities were determined under optimum $\mathrm{pH}$ and temperature conditions. In all cases the initial activity was assumed to be $100 \%$ and used to calculate the enzyme activities as percentages of the initial activity during the incubation period. Each experiment was repeated three times and the mean values were plotted for each experiment.

\section{RESULTS}

\section{Isolation and analysis of thermophilic bacteria consortium}

After subcultivation for 10 times, the thermophilic bacteria consortium, which demonstrated high cellulase activity, was obtained and designated as XM70. A total of twenty-one 16S rRNA gene sequences were deposited in GenBank with 
accession numbers JQ041736-JQ041756 and generated 10 operational taxonomic units (OTUs). Phylogenetic analysis based on 16S rRNA gene sequences showed that the isolates belonged to Firmicutes and Proteobacteria phyla (Fig 1). Among the detected bacteria in the consortium XM70, the following genera occurred: Geobacillus, Desulfotomaculum, Bacillus, Exiguobacterium, Paenibacillus and Enterobacter, respectively.

\section{Optimization of cellulase and sugar production}

The effects of various culture temperatures on cellulase production are presented in Fig 2a. The results reveal that consortium XM70 produced maximum CMCase, FPase and $\beta$-glucosidase at $60{ }^{\circ} \mathrm{C}, 80{ }^{\circ} \mathrm{C}$ and $70{ }^{\circ} \mathrm{C}$, respectively. The optimum $\mathrm{pH}$ for CMCase, FPase and $\beta$ glucosidase are found to be $6.0,7.0$ and 8.0 , respectively (Fig $2 \mathrm{~b}$ ). The time courses of CMCase, FPase and $\beta$-glucosidase activities are shown in Fig. 2c. The cellulase showed very high activities on CMC $(0.052 \mathrm{U} / \mathrm{mL})$, filter paper $(0.044 \mathrm{U} / \mathrm{mL})$, and salicin $(0.046 \mathrm{U} / \mathrm{mL})$ after incubation for 4,2 and 4 days, respectively. SCB was tried as feed stock for production of reducing sugar. Fig $2 \mathrm{~d}$ shows the content of residual reducing sugar in the culture broth within 8 days of incubation. The content of residual reducing sugar increased dramatically in the first 2 days of incubation, and then further increases in incubation time did not favor any obvious increase in sugar production. The maximum amount of residual reducing sugar in the culture broth released from $1 \mathrm{~g}$ of dry SCB was $0.11 \mathrm{~g}$.

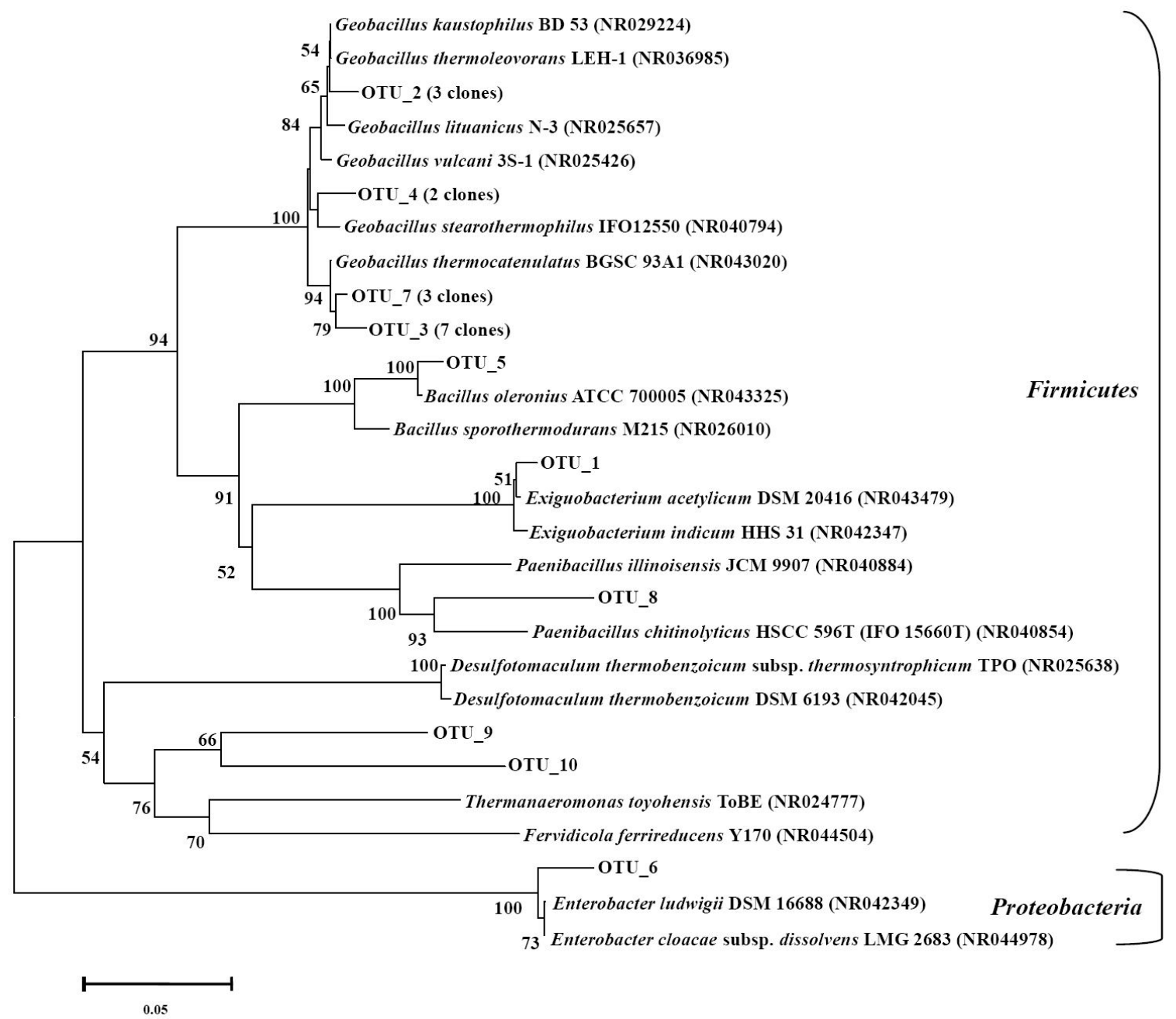

Fig 1: The phylogenetic tree of consortium XM70 (OUT_1 - OUT_10) and related strains based on the 16S rRNA gene sequences. The tree was based on Jukes-Cantor distance and constructed using a neighbor-joining algorithm using MEGA 4.0 software. Reliability of the predicted tree was tested using bootstrapping with 1000 replicates. The scale bar represents 0.05 substitutions per nucleotide position. Numbers at the node are the bootstrap values (\%) 

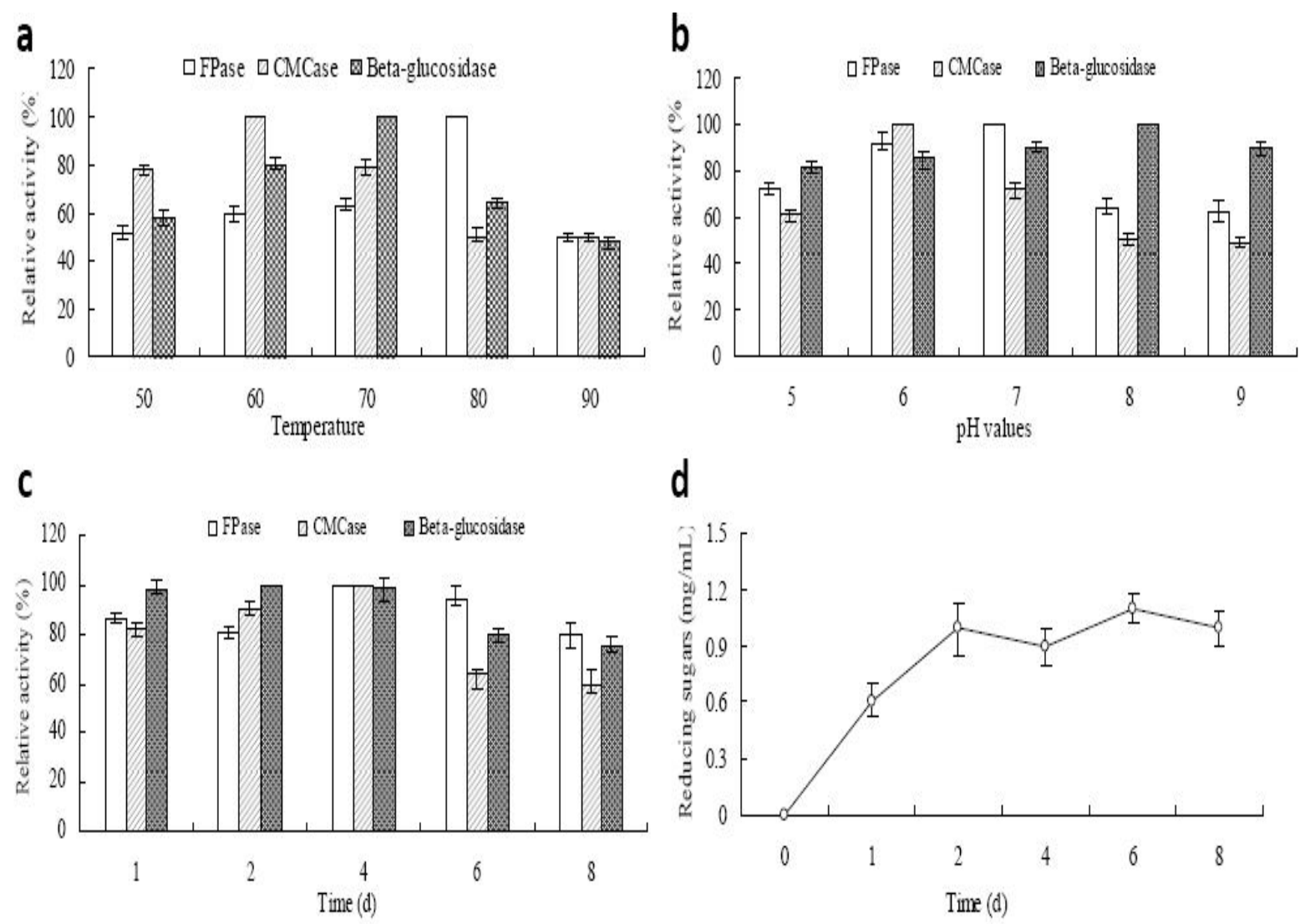

Fig 2: Effects of temperature (a) and $\mathrm{pH}$ (b) on the production of CMCase, FPase and $\beta$-glucosidase from consortium XM70 with pretreated bagasse. Time courses of cellulase production (c) and sugar yield (d) by consortium XM70 in defined medium $\left(\mathrm{pH} 7.0,70{ }^{\circ} \mathrm{C}\right)$

\section{Purification and characterization of XM70- CMCase}

XM70-CMCase was purified by three step procedure including ammonium sulphate precipitation, ion exchange on a DEAE Sephadex A-25 column and gel filtration on a Sephadex G-75 column. The purified XM70CMCase from the culture broth of consortium XM70 following the steps indicated in Table 1 and showed 7.9 -fold increase in activity with a final yield of $65.41 \%$. The specific activity which used CMC as the substrate was $3.77 \mathrm{U} / \mathrm{mg}$ after three steps of purification.

The protein purity was confirmed by the presence of a single band on SDS-PAGE and its relative molecular mass was $31.0 \mathrm{kDa}$ (Fig 3 ). The effect of temperature on the CMCase activity was shown in Fig 4a. The optimal temperature of the purified XM70-CMCase was $70^{\circ} \mathrm{C}$. As shown in Fig $4 \mathrm{~b}$, the optimal $\mathrm{pH}$ for the CMCase activity was 7.0. The CMCase thermostability was assessed by incubating the enzyme at different temperatures $\left(70-100^{\circ} \mathrm{C}\right)$ for different times $(0$ $60 \mathrm{~min}$ ). Results shown in Fig. $4 \mathrm{c}$ indicated that CMCase was optimally stable at $70^{\circ} \mathrm{C}$ and about $90 \%$ activity was retained after incubation for 60 min. The enzyme was found to retain about $70 \%$ of its maximal activity for $60 \mathrm{~min}$ at $80{ }^{\circ} \mathrm{C}$. However, when at 90 and $100{ }^{\circ} \mathrm{C}$, almost all activities were lost after 40 and $30 \mathrm{~min}$ of incubation, respectively.

Table 1: Summary of the purification of XM70-CMCase from consortium XM70

\begin{tabular}{lccccc}
\hline Purification steps & $\begin{array}{c}\text { Protein } \\
(\mathbf{m g})\end{array}$ & $\begin{array}{c}\text { Total activity } \\
(\mathbf{U})\end{array}$ & $\begin{array}{c}\text { Specific activity } \\
(\mathbf{U} / \mathbf{m g})\end{array}$ & $\begin{array}{c}\text { Purification } \\
\text { fold }\end{array}$ & Yield (\%) \\
\hline Crude enzyme & 109.09 & 52.04 & 0.48 & - & - \\
(NH $)_{4}$ SO $_{4}$ precipitation & 37.65 & 44.01 & 1.17 & 2.45 & 84.57 \\
DEAE-Sephadex A-25 & 16.34 & 36.99 & 2.26 & 4.75 & 71.08 \\
Sephadex G-75 & 9.03 & 34.04 & 3.77 & 7.90 & 65.41 \\
\hline
\end{tabular}




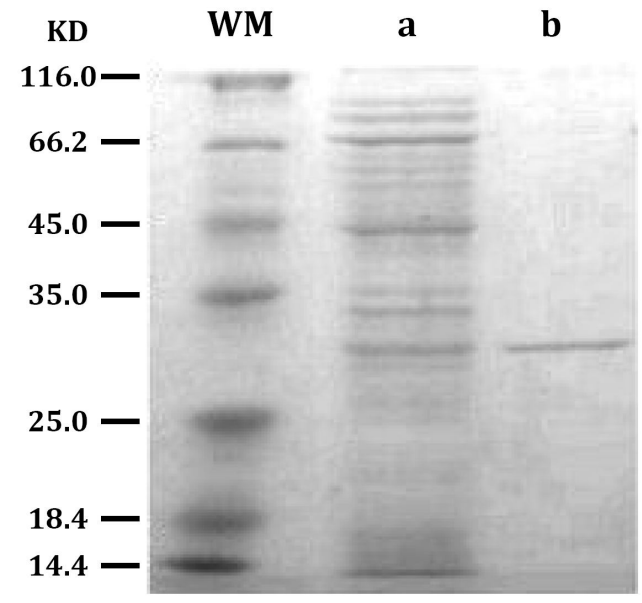

Fig 3: SDS-polyacrylamide gel electrophoresis of the purified XM70-CMCase. Protein molecular weight makers (WM), crude cellulose (a) and purified cellulose (b)
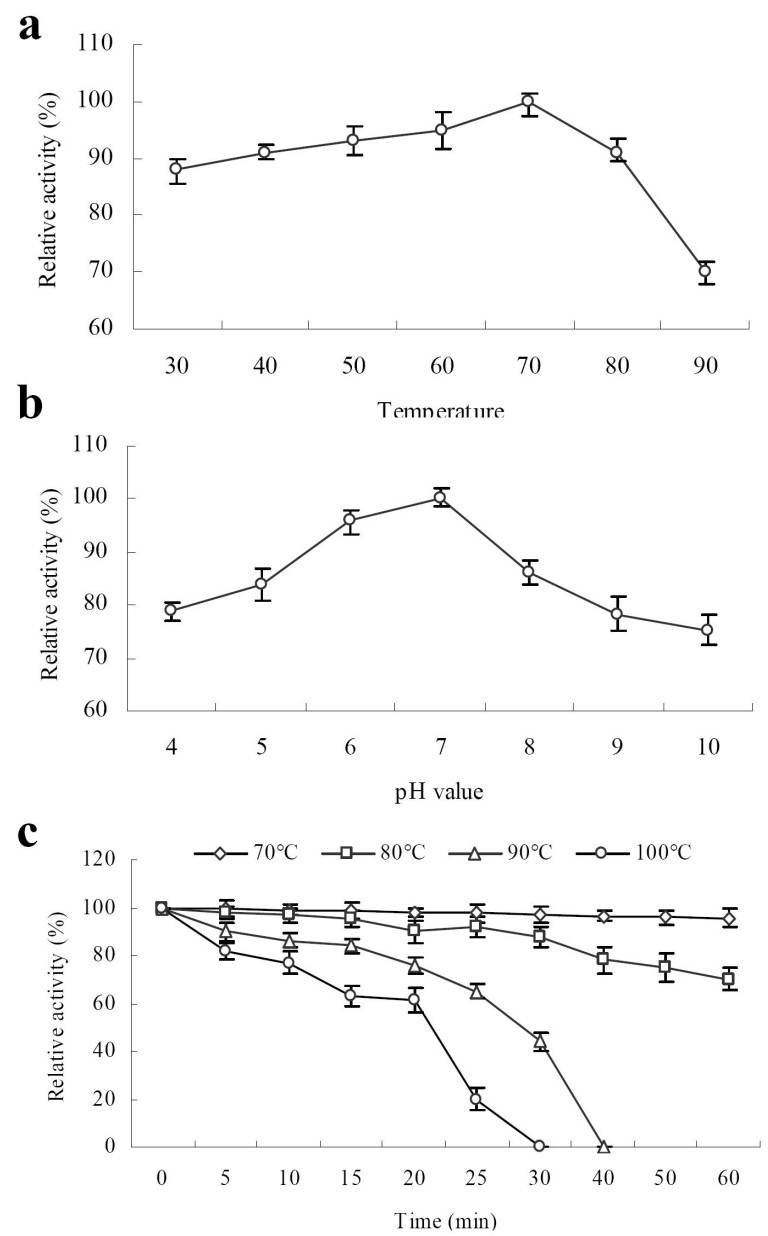

Fig 4: Effects of temperature (a), $\mathrm{pH}(\mathrm{b})$ and thermal stability (c) on CMCase activity of the purified XM70CMCase enzyme

\section{DISCUSSION}

Lignocellulosic biomass is considered to be the most abundant renewable source of sugar. In order to make better use of it, more attention needs to be paid to the cellulase-producing bacteria. Over the past years, culturable cellulase-producing bacteria have been isolated from a wide variety of sources such as composting heaps, decaying plant material from forestry or agricultural waste, the feces of ruminants, soil and organic matter, and extreme environments like hot-springs [26]. The bacteria consortium XM70 which isolated from terrestrial hot spring showed high cellulase activities and produced thermostable cellulases. Consortium XM70 included Geobacillus, Desulfotomaculum, Bacillus, Paenibacillus, Exiguobacterium and Enterobacter species, all of which were grouped in Firmicutes and Proteobacteria. Interestingly, both of them have been reported earlier after being discovered in a hot compost environment and their abilities to produce thermostable cellulases were also demonstrated [11]. Many researchers have purified and characterized cellulases isolated from different types of bacteria. However, bacteria consortium cellulases are often more complex and expressed in multi-enzyme complexes providing increased synergy and functions. A family of cellulases has at least three groups of enzymes (cellobiohydrolases, endo-glucanases and $\beta$ glucosidases) to complete the hydrolysis. Our results presented that production of cellulases requires the presence of the consortium and not a certain microorganism.

Nowadays, there is a great need to obtain sugars from cost-effective fermentation materials [27]. The SCB is a largely abundant and inexpensive fermentation material. However, most of them are not effectively utilized which results in a great waste. The consortium XM70 could hydrolyze pretreated SCB into soluble sugar. Moreover, it also had the ability to utilize SCB to produce the cellulase enzyme complex, which worked on the hydrolysis of cellulose. The total amount of reducing sugar released from $1 \mathrm{~g}$ of dry feed stock catalyzed by the crude enzyme was $0.11 \mathrm{~g}$ g-1 dry SCB. Deswal et al have isolated a brown rot fungus Fomitopsis sp. RCK2010 and used the crude enzymes for saccharification with alkali pre-treated wheat straw and rice straw [28]. The yields of reducing sugar from wheat and rice straw were $0.214 \mathrm{~g} \mathrm{~g}^{-1}$ dry mass and $0.157 \mathrm{~g} \mathrm{~g}^{-1}$ dry mass, respectively. Accumulation of $11 \%$ sugar from delignified SCB in cultural broth showed consortium XM70 has industrial application potential.

Currently, much attention has been paid to the thermophilic bioprocessing of cellulosic biomass to biofuels which, due to the use of elevated temperatures [11]. Thermostable enzymes offer 
several potential advantages in the hydrolysis of lignocellulosic materials [7]. There have been some reports about thermostable cellulase. The thermostable cellulase produced by $E$. coli TCP1 retained more than $60 \%$ of its maximal activity for at least $20 \mathrm{~min}$ at $50-70{ }^{\circ} \mathrm{C}$ and $10 \mathrm{~min}$ at 80 ${ }^{\circ} \mathrm{C}$, respectively [29]. After $20 \mathrm{~h}$ incubation at temperatures ranged from 40 to $60{ }^{\circ} \mathrm{C}$, the CMCase activity of the crude enzyme from Aspergillus fumigatus $\mathrm{Z} 5$ retained more than 80 $\%$ of the original CMCase activity, but at 80 and $90{ }^{\circ} \mathrm{C}$, less than $10 \%$ of the original CMCase activity was remained [30]. The FPase and CMCase activities of the crude enzymes from consortium XM70 were lower than plant cell walldegrading fungi such as Trichoderma and Aspergillus [31]. But the thermal stability and broad $\mathrm{pH}$-optimum were better.

Because the crude enzyme may have a lot of interfering substances for enzyme assays, Jantaporn and Haruyuki purified the CMCase from Cryptococcus sp. S-2 to homogeneity from the supernatant [32]. The optimum temperature for the purified enzyme was between 40 and 50 ${ }^{\circ} \mathrm{C}$, and it retained approximately $50 \%$ of its maximum activity after incubating at $90{ }^{\circ} \mathrm{C}$ for 1 $\mathrm{h}$. In this paper, the maximum CMCase activity of the purified XM70-CMCase was measured at 70 ${ }^{\circ} \mathrm{C}$ and the specific activity which used $\mathrm{CMC}$ as the substrate was $3.77 \mathrm{U} / \mathrm{mg}$. XM70-CMCase also retained approximately $90 \%$ and $70 \%$ of its maximal activity after incubating at $70{ }^{\circ} \mathrm{C}$ and 80 ${ }^{\circ} \mathrm{C}$ for $60 \mathrm{~min}$. Compared with previous studies [33], the maximum CMCase activity of the purified XM70-CMCase is a little lower, but the thermal stability and broad $\mathrm{pH}$-optimum of isolated CMCase at neutral and alkaline $\mathrm{pH}$ make this enzyme promising for application in detergents or denim wash.

\section{CONCLUSION}

Cellulase-secreted consortium XM70 in terrestrial hot spring has high thermo-tolerance. In particular, the purified enzyme has excellent thermal-resistance compared with those obtained previous studies. Their broad temperature and $\mathrm{pH}$ activity range as well as utilization of sugarcane bagasse constitute a contribution to current knowledge of bacterial consortium and their potential uses such as in the biofuel, animal feed and paper industries.

\section{ACKNOWLEDGEMENT}

This work was financially supported by the National Natural Science Foundation of China (no. 41306181), China Postdoctoral Science
Foundation (no. 2014T70602), JK grant from the Scientific Research Project of Education Department of Fujian Province, China and FAFU Science Fund for Distinguished Young Scholars (no. XJQ201417).

\section{REFERENCES}

1. Maki M, Leung KT, Qin W. The prospects of cellulaseproducing bacteria for the bioconversion of lignocellulosic Biomass. Int J Biol Sci 2009; 5: 500516.

2. Dong $X Q$, Yang JS, Zhu N, Wang ET, Yuan HL. Sugarcane bagasse degradation and characterization of three white-rot fungi. Bioresour Technol 2013; 131: 443-451.

3. Satyanarayana KG, Guimaraes JL, Wypych F. Studies on lignocellulosic fibers of Brazil. Part l: source, production, morphology properties and applications. Composites Part A 2008; 38: 1694-1709.

4. Karp SG, Faraco V, Amore A, Birolo L, Giangrande C, Soccol VT, Pandey A, Soccol CR. Characterization of laccase isoforms produced by Pleurotus ostreatus in solid state fermentation of sugarcane bagasse. Bioresour Technol 2012; 114: 735-739.

5. Soccol CR, Vandenberghe L, Medeiros ABP, Karp SG, Buckeridge $M$, Ramos $L P$, Pitarelo $A P$, FerreiraLeitão V, Gottschalk LM, Ferrara MA, Bon EPS, Moraes LMP, Araújo J, Torres F. Bioethanol from lignocelluloses: status and perspectives in Brazil. Bioresour Technol 2011; 101: 4820-4825.

6. Kuhad RC, Gupta R, Singh A. Microbial cellulases and their industrial applications. Enzyme Res 2011; 280696.

7. Bhalla A, Bansal N, Kumar S, Bischoff KM, Sani RK. Improved lignocellulose conversion to biofuels with thermophilic bacteria and thermostable enzymes. Bioresour Technol 2013;128: 751-759.

8. Yeoman CJ, Han Y, Dodd D, Schroeder CM, Mackie RI, Cann IK. Thermostable enzymes as biocatalysts in the biofuel industry. Adv Appl Microbiol 2010; 70: 155

9. Liu D, Zhang R, Yang X, Xu Y, Tang Z, Tian W, Shen $Q$. Expression, purification and characterization of two thermostable endoglucanases cloned from a lignocellulosic decomposing fungi Aspergillus fumigatus Z5 isolated from compost. Protein Expr Purif 2011; 79: 176-186.

10. Voutilainen SP, Murray PG, Tuohy MG, Koivula A. Expression of Talaromyces emersonii cellobiohydrolase Cel7A in Saccharomyces cerevisiae and rational mutagenesis to improve its thermostability and activity. Protein Eng Des Sel 2010; 23: 69-79.

11. Rastogi G, Bhalla A, Adhikari A, Bischoff KM, Hughes $S R$, Christopher LP, Sani RK. Characterization of thermostable cellulases produced by Bacillus and 
Geobacillus strains. Bioresour Technol 2010; 101: 8798-8806.

12. Lee YJ, Kim BK, Lee BH, Jo KI, Lee NK, Chung CH, Lee $Y C$, Lee JW. Purification and characterization of cellulase produced by Bacillus amyoliquefaciens $D L-$ 3 utilizing rice hull. Bioresour Technol 2008; 99: 378386.

13. Gan Q, Allen SJ, Taylor G. Kinetic dynamics in heterogeneous enzymatic hydrolysis of cellulose an overview, an experimental study and mathematical modeling. Process Biochem 2002; 38: 1003-1018.

14. Sun $Y$, Cheng J. Hydrolysis of lignocellulosic material from ethanol production: A review. Bioresour Technol 2002; 83: 1-11.

15. Ng IS, Li CW, Yeh YF, Chen PT, Chir JL, Ma CH, Yu SM, Ho TD, Tong CG. A novel endo-glucanase from the thermophilic bacterium Geobacillus sp. 70PC53 with high activity and stability over a broad range of temperatures. Extremophiles 2009; 13: 425-435.

16. Rastogi G, Muppidi GL, Gurram RN, Adhikari A, Bischoff KM, Hughes SR, Apel WA, Bang SS, Dixon DJ, Sani $R K$. Isolation and characterization of cellulosedegrading bacteria from the deep subsurface of the homestake gold mine, Lead, South Dakota, USA. J Ind Microbiol Biotechnol 2009; 36: 585-598.

17. Weisburg WG, Barns SM, Pelletier DA, Lane DJ. $16 S$ ribosomal DNA amplification for phylogenetic study. J Bacteriol 1991; 173: 697-703.

18. Tamura K, Dudley J, Nei M, Kumar S. MEGA4: molecular evolutionary genetics analysis (MEGA) software version 4.0. Mol Biol Evol 2007; 24: 1596-1599.

19. Zhang YH, Himmel ME, Mielenz JR. Outlook for cellulase improvement: screening and selection strategies. Biotechnol Adv 2006; 24: 452-481.

20. Ghose TK. Measurement of cellulase activities. Pure Appl Chem 1987; 59: 257-268.

21. Chahal DS. Solid-state fermentation with Trichoderma reesei for cellulase production. Appl Environ Microbiol 1985; 49: 205-210.

22. Miller GL. Use of dinitrosalicylic acid reagent for determination of reducing sugar. Anal Chem1959; 31: 426-428.

23. Gupta V, Trivedi $N$, Kumar $M$, Reddy CRK, Jha $B$. Purification and characterization of exo- $\beta$-agarase from an endophytic marine bacterium and its catalytic potential in bioconversion of red algal cell wall polysaccharides into galactans. Biomass Bioenerg 2013; 49: 290-298.

24. Bradford MM. A rapid and sensitive method for the quantitation of microgram quantities of protein utilizing the principle of protein-dye dinding. Anal Biochem 1976; 72: 248-254.

25. Laemmli UK. Cleavage of structural proteins during the assembly of the head of Bacteriophage T4. Nature 1970; 227: 680-685.

26. Doi RH. Cellulases of mesophilic microorganisms: cellulosome and nocellulosome producers. Ann NY Acad Sci 2008; 1125: 267-279.

27. Saha BC, Iten LB, Cotta MA, Wu YV. Dilute acid pretreatment, enzymatic saccharification and fermentation of wheat straw to ethanol. Process Biochem 2005; 40: 3693-3700.

28. Deswal D, Khasa YP, Kuhad RC. Optimization of cellulase production by a brown rot fungus Fomitopsis sp. RCK2010 under solid state fermentation. Bioresour Technol 2011; 102: 60656072.

29. Li X, Bhaskar R, Yang HJ, Wang D, Miao YG. Screening and identification of new isolate: thermostable Escherichia coli with novel thermoalkalotolerant cellulases. Curr Microbiol 2009; 59: 393-399.

30. Liu D, Zhang R, Yang X, Wu H, Xu D, Tang Z, Shen Q. Thermostable cellulase production of Aspergillus fumigatus Z5 under solid-state fermentation and its application in degradation of agricultural wastes. Int Biodeter Biodegr 2011; 65: 717-725.

31. Mahamud MR, Gomes DJ. Enzymatic saccharification of sugar cane bagasse by the crude enzyme from indigenous fungi. J Sci Res 2012; 4: 227-238.

32. Jantaporn $T$, Haruyuki I. Thermal Stability of Cryptococcus sp S-2 carboxymethyl cellulase (CSCMCase) having a cellulose binding domain from a fungal exoglucanase: comparison to recombinant CSCMCase. Songklanakarin J Sci Technol 2009; 31: 361-365.

33. Zhao J, Shi P, Li Z, Yang $P$, Luo H, Bai Y, Wang Y, Yao B. Two neutral thermostable cellulases from Phialophora sp. G5 act synergistically in the hydrolysis of filter paper. Bioresour Technol 2012; 121: 404-410. 